\title{
CRITICAL REGIONALISM IN THE POST-COLONIAL ARCHITECTURE OF THE INDIAN SUBCONTINENT
}

\author{
Sumantra MISRA ${ }^{1, *}$, Manjari CHAKRABORTY², N. R. MANDAL $^{3}$ \\ 1, 2 Department of Architecture, Birla Institute of Technology, Mesra, Ranchi, Jharkhand - 835215, India \\ ${ }^{3}$ Department of Planning, School of Planning and Architecture, Neelbad Road, Near IISER Institute, Bhauri, \\ Bhopal, Madhya Pradesh - 462030, India
}

Received 27 April 2017; accepted 21 November 2017

\begin{abstract}
Critical Regionalism as expounded by Kenneth Frampton has found its use in many parts of the world as a reaction to the international architecture practised in the Western world. India, which was deprived of exposure to the advanced developments in architecture in the US and Europe was at one stroke brought into world contact after gaining independence. This paper traces the exposure of the Indian architects to Western training and philosophy and how they developed their works to suit the regional context. Important aspects of the paper are mentioned below:

- International exposure of the Indian architects after independence.

- Their designs and their approaches to the creation of an Indian flavour on their return to homeland.

- Examined the works of a few prominent architects and inferred on their special regional contributions.
\end{abstract}

Keywords: architectural design, design theory, case based reasoning, architecture, architecture of public buildings, contemporary architecture, modern architecture.

\section{Introduction}

"There is the paradox: how to become modern and return to sources; how to revive an old, dormant civilisation and take part in universal civilisation," - Paul Ricoeur, History and Truth (Ricœur, 1965).

"It is to symbolise this universal fellowship of man, the unity of all creation, that the Indian loves to crowd into his picture all forms of teeming life - uses every constructive feature to symbolise the universal law of the One-inMany - Ernest Binfield Havell (Binfield Havell, 1912).

The phrase "critical regionalism" was first used by the architectural theorists Alexander Tzonis and Liane Lefaivre wherein they were critical; and even cynical in some parts, about the exaggeration that was post-modernism. The notion of Critical Regionalism was introduced 25 years ago by Alexander Tzonis to draw attention to the approach taken by a group of young German architects in Europe. This group was working on an alternative to the postmodernism that, with few exceptions, had not really taken architecture, as it meant to do, out of a state of stagnation and disrepute by the reintroduction of historical knowledge and cultural issues in design (Tzonis \& Lefaivre, 1980). But, it was Frampton who first formally discussed the issue and placed it in his book, Towards a Critical Regionalism: Six Points for an Architecture of Resistance. The six points stated by him have been used as reference while looking at the works of the South Asian architects.

\section{Objective}

This paper essentially sets out to establish how the "Six Points for an Architecture of Resistance" were satisfied by prominent practising architects of the time to bring in some semblance of Critical Regionalism in Post-Independence architecture in the Indian subcontinent.

International architecture had become all pervading, and in fact, non-contextual. People the world over had their own traditions, cultures, languages and religions which were being emphasized by the people to provide themselves an identity and a place in the vastness of the world, but this needed to be also reflected in the architecture that came up in the different regions of the world.

In those uncertain times in architecture Kenneth Frampton propagated the idea of Critical Regionalism through his publications in which he highlighted the

${ }^{\star}$ Corresponding author. E-mail: sumantra.misra@gmail.com 
issues stated below as important to any work where this philosophy has been used.

\section{Study area}

Six Points for Architecture of Resistance (Frampton, 1983):

\section{Critical regionalism and world culture;}

The architecture of a region should be rooted locally and have a connect with International architecture.

The fundamental motive is to combine the impact of universal style with elements derived from the intrinsic culture of a particular place.

The resistance of the place-form;

The form is a space and when the space is provided with an identity it becomes a place. The architecture should not be a piece of free standing object, but should adapt the characteristic of the local place.

Culture vs. nature: topography, context, climate, light and tectonic;

The geology, geography, climate and overall context differ in the different parts of the globe; hence the local architecture should reflect them in their designs.

The visual vs. the tactile;

Perception of architecture visually as well as by addressing the range of other human senses (tactile, audio, taste and hearing).

\section{Culture and civilisation;}

According to Frampton, there is a huge role of technological improvements and the financial waves that limit the scope of urban design in many ways. He claims that the architectural thoughts are divided into two parts one is profits of technological predication on the product, and the other one is the provision of a compensatory façade to cover the harsh realities of this universal system.

The rise and fall of the Avant-Garde;

Frampton states that the movements in architecture in the mid $19^{\text {th }}$ century, was the reaction to the architecture of the industrial revolution period. Thereafter Neo classical form and Gothic revival was developed just to make architecture humane. The local style of architecture was neglected.

According to Frampton's proposal, critical regionalism should adopt modern architecture, critically, for its universal progressive qualities but at the same time value should be placed on the geographical context of the building. Emphasis, Frampton says, should be on topography, climate, and light; on tectonic form rather than on scenography (i.e. painting theatrical scenery) and should be on the sense of touch rather than visual sense. Frampton draws on phenomenology for his argument.

It can be summarized that Critical Regionalism was conceived where International Style and Postmodernism met with their justified deaths.

The paradigm of research that this paper deals with can be said to be in the area of Theory of Architecture. Though there is a huge overlap between Theory of Architecture and Theory of Design this paper deals with archi- tecture in particular dealing more with styles and history rather than design processes.

\section{Methodology}

The methods adopted for the investigation regarding the issue of regional criticism and its utilisation in the South Asian have been looked into through the works of the great South Asian masters who worked relentlessly to promote regional contemporary architecture. The analysis has been spread over six different components mentioned under:

Impressionable years.

Early Architectural Education.

International Exposure.

Important works.

Design Philosophy.

With reference to the six points of resistance.

Inferences have been made appropriately and photographs of suitable architecture have been used abundantly to support the arguments presented. The architects selected for the evaluation have considerable published materials about them which makes writing such a paper feasible.

The scope of this paper permits us to discuss only architects from the Indian subcontinent who have attempted Critical Regionalism (in the Frampton sense) in their ideas and works namely:

MUZHARUL ISLAM,

B. V. DOSHI,

CHARLES CORREA,

CHRISTOPHER BENNINGER,

GEOFFREY BAWA,

RAJ REWAL.

The results of this exercise provides us with a convincing inference that Critical Regionalism has found its true place in South Asia.

\section{Data base}

\section{MAZHARUL ISLAM}

\section{Impressionable years}

He was born on the $25^{\text {th }}$ of December 1923 in Kuepara village of Chittagong. His father was a professor of mathematics who worked throughout his career in different government colleges - due to which his childhood and school life was mostly spent in Rajshahi, Chittagong and Krishnonagar. An important part of his childhood memory is centered around the Jamindarbari of his maternal grandparents in Sundarpur village in Murshidabad. Overall, it can be said that, his greater family belonged to a financially solvent, educated Bengali elite class.

Early architectural education

In 1942 he did Bachelor of Science, Calcutta, University, Calcutta. In 1946 he completed his Bachelor of Engineering, Calcutta University, Calcutta.

\section{International exposure}

He got a Scholarship under Post-War Development and 
got his Bachelor of Architecture from Oregon University, USA. He followed that up with a British Council scholarship to study tropical architecture at the AA School of Architecture, London. He also won Rockefeller Fellowship for studying the state of Contemporary Architecture in Europe. In 1961, he completed his post-graduation under Paul Rudolph from Yale University. At Yale, Stanley Tigerman was one of his classmates, and there he came in touch of Louis I Kahn (Muzharul Islam Archive, n.d.). Important works

Some of his prominent works include - Jahangirnagar University, Chittagong University, Central Public Library, Charukala Institute, Railway Rehabilitation Zone, National Library of Bangladesh (Figure 1), the Azimpur Estate, Rangmati township, BCSIR Laboratory Buildings, National Institute of Public Administration Building and a number of Polytechnic Institutes. Islam designed the master plan of Dhaka City. He also created the logo for the government of Bangladesh (Ashraf, n.d.).

\section{Design philosophy}

While he was still a student abroad, he had this deep belief that every country should have its own architectural character. The architecture of a place depends on its geography, climate and the manifestations of its own culture.

With reference to the six points of resistance

Muzharul Islam, born in rural Bangladesh had a wide International exposure through his education and his work with renowned architects such as Louis Kahn, Paul Rudolph and Stanley Tigerman.

He is recognised as the Grand Master of regional modernism in South Asia.

He has effectively imbibed all the Six Points for Architecture of Resistance in his works to a reasonable degree.

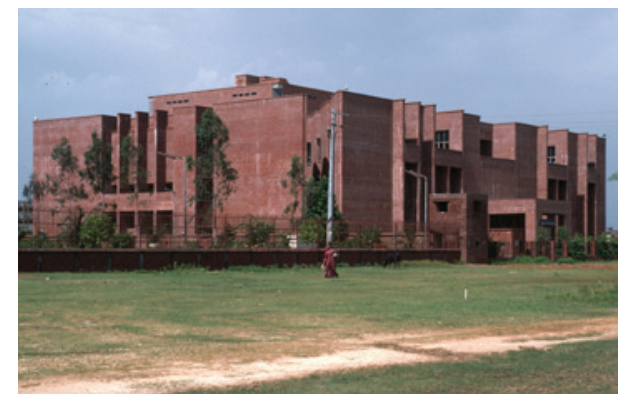

Figure 1. National Library of Bangladesh, Dhaka

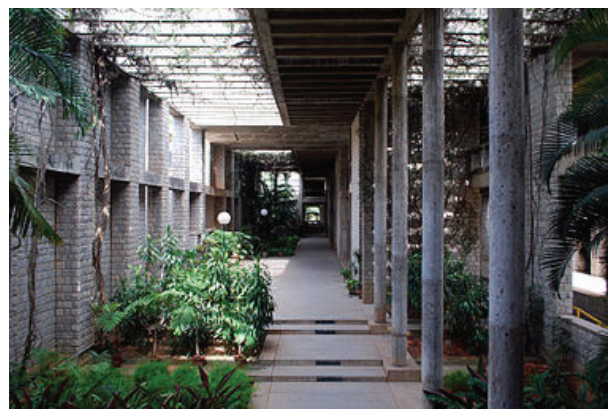

Figure 2. IIM Bangalore, Pedestrian Pathways
The issues aspects of Universal style with elements derived from intrinsic culture stands out as an exemplar.

He has deliberately avoided any indulgence in Avante Garde typology due to his maturity and societal standing.

Mazharul Islam's works give an identity to the expression of a new born nation in all its characteristic flavours.

\section{B. V. DOSHI}

Impressionable years

Balkrishna Vithaldas Doshi was born in Pune, India in 1927. Doshi's family had been in thefurniture business for two generations. Some of his early memories include his Grandparent's house in Ravivar Peth, Pune - with wooden balconies, tile roofs, and kilns outside. These memories have made a deep impact on his later works.

Early architectural education

He studied at the J. J. School of Architecture, Mumbai.

\section{International exposure}

After having worked for four years between 1951-54 with Le Corbusier in Paris, Doshi worked closely with Louis Kahn and Anant Raje, when Kahn designed the campus of the Indian Institute of Management, Ahmedabad. In 1958 he was a fellow at the Graham Foundation for Advanced Studies in the Fine Arts (Nangia, 2006).

\section{Important works}

He was an educator and institution builder. Of the many institutions he built, the most famous is the Centre for Environmental Planning and Technology (CEPT).

His most important works include - Sangath, BV Doshi's office, Ahmedabad; Centre for Environment and Planning Technology (CEPT), Ahmedabad; Indian Institute of Management Bangalore (Figure 2); National Institute of Fashion Technology, Delhi; Amdavad ni Gufa, Ahmedabad; Aranya Low Cost Housing (Figure 3), Indore; IFFCO Township, Kalol; Sawai Gandharva, Pune; Premabhai Hall, Ahmedabad; Tagore Hall, Ahmedabad; Vidyadhar Nagar, Jaipur (Doshi \& Steele, 1998).

Design philosophy

He believed in Architecture being for a place and for people.

Doshi worked under the leadership of Le Corbusier during the building of Chandigarh and used many of the techniques of Corbusier such as exposed concrete and

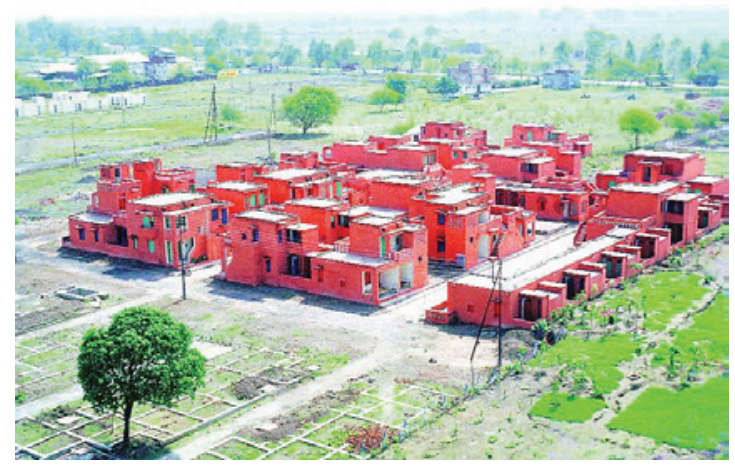

Figure 3. Aranya Low Cost Housing, Indore 
brick in his earlier works but developed his own style in subsequent years.

With reference to the six points of resistance

From the beginning B V Doshi was very strongly grounded in Indian traditions. He went to school in a village near Pune and then studied architecture in the Sir J J School of Arts. He found his international experience while studying as a fellow at the Graham Foundation for Advanced Studies in the Fine Arts and while working with Le Corbusier.

"Corbusier had a profound impact on Doshi", says Ramachandran, "but he has always sought to interpret Corbusier's modernism through local conditions of site, climate and available technology." (Inglis, 2009).

It may not be out of place to mention here that his works were outstanding because of the sculptural tendencies exhibited in his buildings. But rarely can the idea of place-form as proposed by Kenneth Frampton be seen in his works. The Amdavad Ni Gumfa being an exception.

In all of his works, Doshi has been honest to the surroundings, the materials and the general ethos of the region.

However, he has incorporated extensively the geology, climate and local context in his creations.

\section{CHARLES CORREA}

\section{Impressionable years}

Correa was born on 1 September 1930 in Secunderabad. Of the many reasons for choosing a profession, a love of model trains is not the obvious one. Yet Charles Correa, who has died aged 84, confessed that his introduction to architecture came through the patterns that could be created by changing the layout of rails and the environments around them.

\section{Early architectural education}

Correa began his higher studies at St. Xavier's College, at the University of Bombay (now Mumbai).

\section{International exposure}

He went on to study at the University of Michigan in Ann Arbor (1949-53) and the Massachusetts Institute of Technology (MIT) in Cambridge, Massachusetts (1953-55). In
1958 he established his own Mumbai based professional practice (Encyclopaedia Britannica, n.d.). He was awarded the Padma Shri in 1972, and the second highest civilian honour, the Padma Vibhushan was awarded by Government of India in 2006. He was also awarded the 1984 Royal Gold Medal for architecture, by the Royal Institute of British Architects.

Important works

His works include the carefully detailed memorial Mahatma Gandhi Memorial Museum at the Sabarmati Ashram in Ahmedabad, the Kanchanjunga Apartment tower in Mumbai, the Jawahar Kala Kendra in Jaipur (Figure 4), the planning of Navi Mumbai, MIT's Brain and Cognitive Sciences Centre in Cambridge, and most recently, the Champalimaud Centre for the Unknown in Lisbon.

Design philosophy

In all of his designs he places special emphasis on prevailing resources, energy and climate as major determinants in the ordering of space. His authentic modernity superseded stale colonial imports.

With reference to the six points of resistance

One of the earliest works of Charles Correa was the Gandhi Smarak Sangrahalaya in Sabarmati Ashram.

Having being trained in MIT and Harvard where a western orientation was given to his learning Correa was confronted with the dilemmas between the American thoughts and concepts and the Indian ethos apropos Gandhian ideologies. From this point onwards Charles Correa has strongly used Vedic symbolism/iconography in most of his works.

However his past training in Western design though has made his design work hang on to the International or Universal design thought. It is also visually very compelling while the spaces created inside his buildings have the other human senses come into play.

In most of his projects he has been able to establish a sense of place in the beautifully organised spaces he has designed. Some of them are City Centre in Kolkata and Bharat Bhawan in Bhopal.

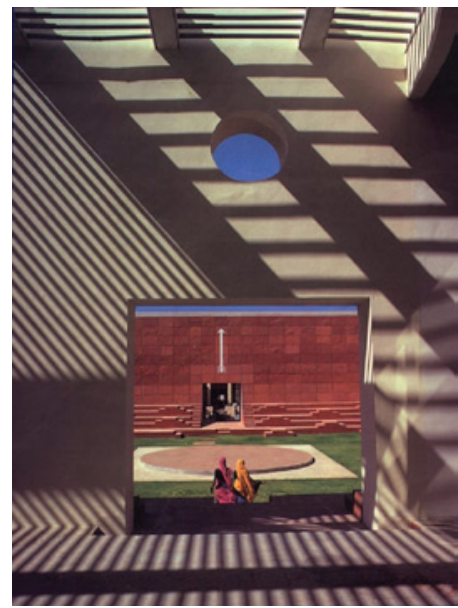

Figure 4. Jawahar Kala Kendra, Jaipur

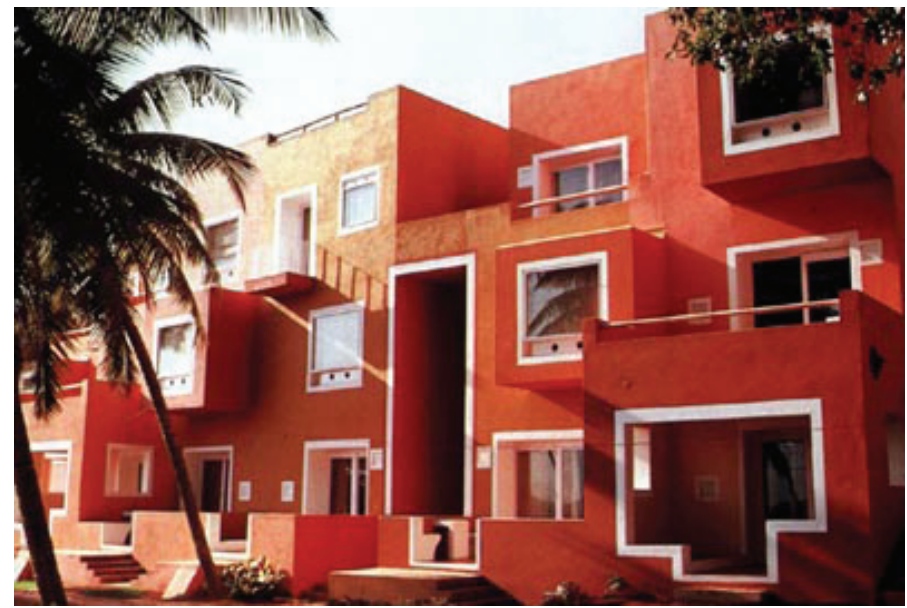

Figure 5. Cidade de Goa 
In some of his projects like the Cidade De Goa (Figure 5) he has tried to break away from the monotonous to the Avante Garde.

Correa's works have a definitive signature of the master in terms of the history of the place linking it to the entire world.

\section{CHRISTOPHER BENNINGER}

\section{Impressionable years}

Born in Hamilton, Ohio in 1942, Prof. Christopher Charles Benninger grew up in America. He was influenced by Frank Lloyd Wright's organic architecture as a boy. At the age of twelve he read The Natural House by Wright, which left an indelible mark on him, that can be seen in his work today.

\section{Early architectural education}

He studied urban planning at the Massachusetts Institute of Technology and architecture at Harvard's Graduate School of Design, where he later taught.

\section{International exposure}

On the invitation of B. V. Doshi, in 1971 he resigned from his tenured post at Harvard and shifted to Ahmedabad, India as a Ford Foundation Advisor to the Ahmedabad Educational Society, where he founded the School of Planning (Lang, 2002). In 1976 he shifted to Pune, India, where he founded the Center for Development Studies and Activities.

While in Ahmedabad he innovated the concept of Site and Services, an approach to housing providing access to shelter via developed small plots, allowing poor families to construct their own homes, according to their means.

This was the first shelter program funded by the Government of India for the economically weaker section of society. In 1976-79, using funding from the Housing and Urban Development Corporation (HUDCO). He built a township for low income households at Yusafguda, in Hyderabad with over two thousand houses, public amenities and shopping centres. He took similar shelter projects in Kolkata.

\section{Important works}

Center for Development Studies and Activities, the Mahindra United World College of India, the Samundra Institute of Maritime Studies, the YMCA International Camp, Nilshi, India, the Kirloskar Institute of Advanced Management Studies, National Ceremonial Plaza in Thimphu, Bhutan
(Figure 6) and the International School Aamby.

Benninger's planning work includes development plans for six regional capitals in Sri Lanka, three new towns in Bhutan, the Development Plans of Kalyan and Thane in the Mumbai Metropolitan Region, the plans for twentyeight urban centres in Madhya Pradesh and the Capital City of Bhutan, Thimphu.

He also guided the planners of the Katenga Regional Development Authority in their design of the new economic region in Terengganu, an emerging region in the North-eastern region of Malaysia.

\section{Design philosophy}

Benninger often quotes Gandhi's indicative, "Live in a village and plan for the world".

With reference to the six points of resistance

Christopher is an American Indian architect having a grounding in both the American and the Indian design thought. He has used his American exposure in the buildings that he has designed by using the concepts of universality; while at the same time, making a strong connect with the architecture and traditions to be seen locally.

Most of his works are simply international in flavour but in his projects designed in Thimpu, Bhutan he got the opportunity to merge the International outlook with a very strong intrinsic culture of Bhutan.

From the point of view of place and form there is little evidence of his work achieving any such trait.

As with all sensitive architects he too has very well dealt with the issues of topography, climate and context.

In some of his projects he has even taken into consideration the visual-tactile aspects expressed by Kenneth Frampton through the use of relief in concrete, stone and timber particularly in Mahindra International School and Thimpu projects.

He has rarely tried to produce works which will be considered as Avante Garde.

Benninger has a capacity of designing projects which are very rooted to the context - yet can be seen as an international statement.

\section{GEOFFREY BAWA}

Impressionable years

Deshamanya, Geoffrey Manning Bawa was a Sri Lankan architect born in the year 1919 to wealthy parents of

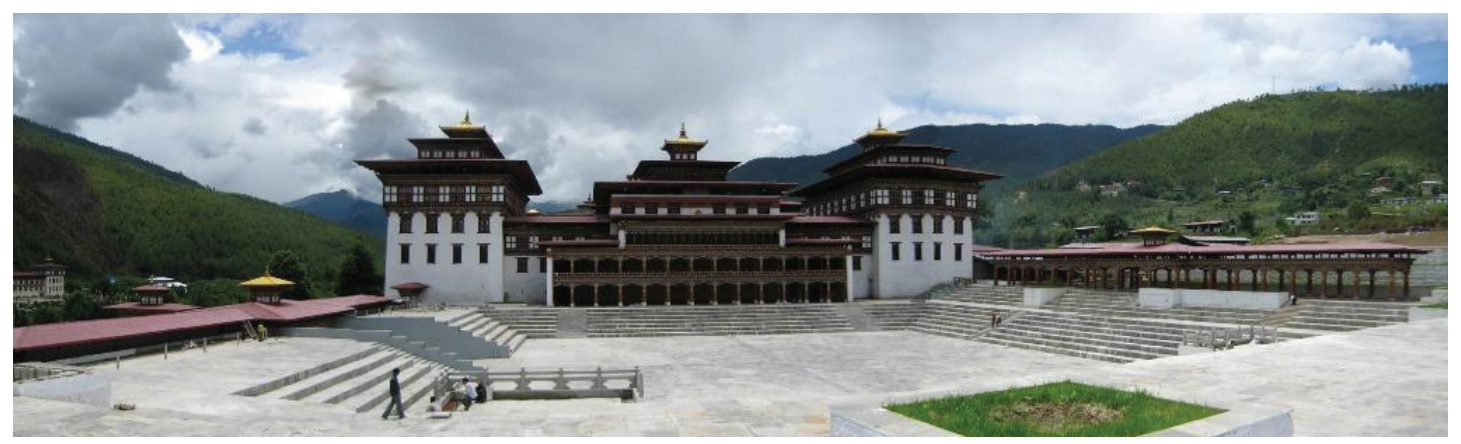

Figure 6. Tshechu Ground or the National Ceremonial Plaza in Thimphu, Bhutan 
mixed European and Ceylonese descent. He read English and law in London after which he travelled widely in Europe. However he returned to Ceylon in 1948 and brought a rubber estate off Bentota called Lunuganga which he attempted to convert into an Italian garden but he felt the lack of expertise in himself which made him to become an apprentice in an architectural firm Edwards Reid and Begg in Colombo.

Early architectural education

His professional training in architecture was obtained from the Architectural Association, London. After qualifying he returned to steer Reid's practice in 1958 (Bawa, n.d.).

International exposure

In 1959 Danish architect Ulrik Plesner joined the firm and the two created many buildings together in their distinct style, sometimes called tropical modernism. Plesner left the island in 1967. Bawa became an Associate of the Sri Lanka Institute of Architects in 1960. An ensuing close association with a coterie of like-minded artists and designers, including Ena de Silva, Barbara Sansoni and Laki Senanayake, produced a new awareness of indigenous materials and crafts, leading to a post colonial renaissance of culture.

\section{Important works}

Bawa's portfolio of works is exhaustive both in terms of location and typologies. Few of the notable works are: Lunuganga Estate; Good Shepherd Convent; State Mortgage Bank; Meena Muttiah Hospital for the Kumarni of Chettinad, Chennai; Institute for Integral Education; Heritance Kandalama, Dambulla (Figure 8); Sri Lankan Parliament Building; University of Ruhuna (Figure 7); Institute of Engineering and Technology, Indore; Banyan Tree Hotel; Official Residence of the President, Sri Lanka.

\section{Design philosophy}

Bawa's style is eclectic, very climate conscious and uncompromising on aesthetics and local flavour.

A building can only be understood by moving around and through it and by experiencing the modulation and feel the spaces one moves through-from the outside into verandah, then rooms, passages, courtyards.

Architecture cannot be totally explained but must be experienced. - Geoffrey Bawa.

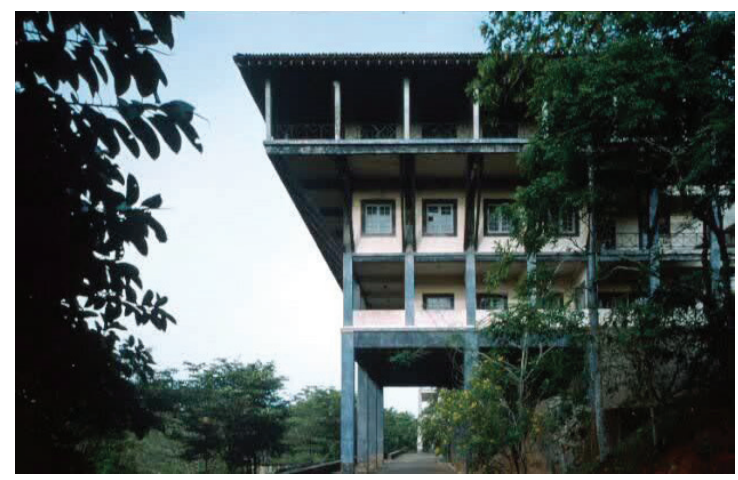

Figure 7. University of Ruhuna, Matara, Sri Lanka
With reference to the six points of resistance

The most important issue of critical regionalism has been always been included by Bawa in all his works. He has been highly personal in his approach, evoking the pleasures of the senses that go hand in hand with the climate, landscape, and culture of ancient Ceylon (present day Sri Lanka). He brings together an appreciation of the Western humanist tradition in architecture with needs and lifestyles of his own country. He was the principal force behind TROPICAL MODERNISM.

His work respected the site and context, light and shade accommodating the theory of Kenneth Frampton of the issue of Culture verses nature point of resistance. Water bodies have been essential part of Bawa's architecture.

The issue of culture and civilization has been used extensively with the use of natural rural material over modern buildings which have elaborate technological inputs as in the hotels and Universities he designed.

Rarely has Avanade Garde buildings been designed by Bawa.

\section{RAJ REWAL}

Impressionable years

Raj Rewal was born in Hoshiarpur, Punjab, India but lived in Delhi and Shimla from 1934-1951. He attended Harcourt Butler higher secondary school. Between 1951-1954 he attended the Delhi School of Architecture in New Delhi.

Early architectural education

Between 1951-1954 he attended the Delhi School of Architecture in New Delhi.

International exposure

Then he moved to London in 1955 where he lived until 1961. He attended the architectural association school of architecture for one year and the Brixton school of building, London from 1956-60.

Raj Rewal worked at Michel Ecochards's office in Paris before starting his practice in New Delhi in 1962.

Important works

Between 1963-72, he taught at the School of Planning and Architecture, Delhi.

Among his better known projects are the Hall of Nations at the Pragati Maidan Exhibition Centre, Asian Games Village (Figure 10), Central Institute of Educa-

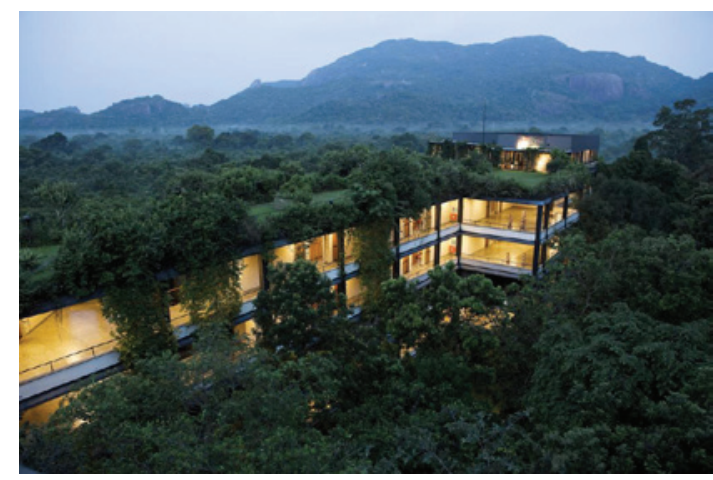

Figure 8. Heritance Kandalama, Dambulla, Sri Lanka 


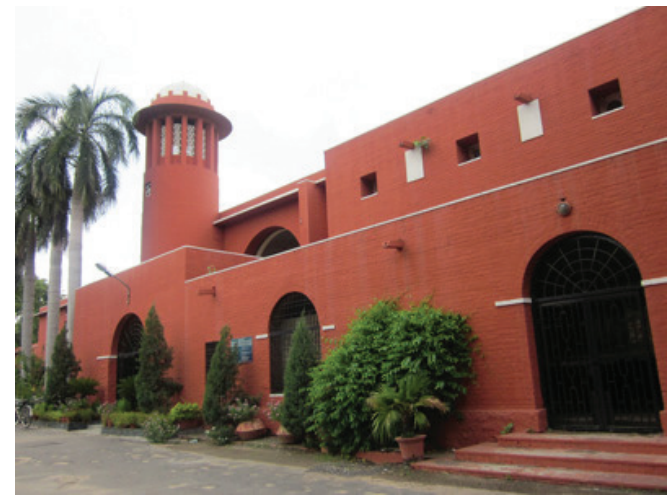

Figure 9. Central Institute of Educational Technology, New Delhi

tional Technology, New Delhi (Figure 9), the Parliament Library in New Delhi and NCBS (National Centre for Biological Sciences) campus at Bangalore (History | NCBS, n.d.). In 1986, he became the curator of the exhibition "Traditional Architecture in India" for the Government of India organised festival of India in Paris. He also designed an architectural college (SIUPA) in Rohtak. It is sad to state here that the importance of architectural heritage that contributed to the formative years of Indian contemporary architecture could not be recognised by the instituted government and the people of India lost a symbol of progressive Critical Regionalism when the Hall of nations was demolished in April, 2017.

\section{Design philosophy}

He created a revolution in geometric design systems. Creation of geometric systems and responding visual imageries are apparent in Raj Rewal's architectural works.

According to him a functional design should be involved with a specific emotional flavour or poetic mood to which he refers as the rasa of the building.

His buildings give the perception of traditional morphology into a contemporary equivalent.

He emphasised on structural masses and natural buildings.

His extensive use of stone and stone grid for structural ornamentation for expressive purpose of any structural system.

His buildings include pure structural expression, cubic volumes.

With reference to the six points of resistance

In Lisbon, he has bonded steel and stone to act in unison as a structural support system.

Reflects a concern for climatic sensitivity and local materials.

Raj Rewal grew up as a child in the rustic setting of Hoshiarpur, Punjab and had his architectural training in the erstwhile Delhi School of Architecture, presently known as School of Planning and Architecture.

He obtained an international exposure at the Architectural Association School of architecture in London and from his projects which he executed in Iran.

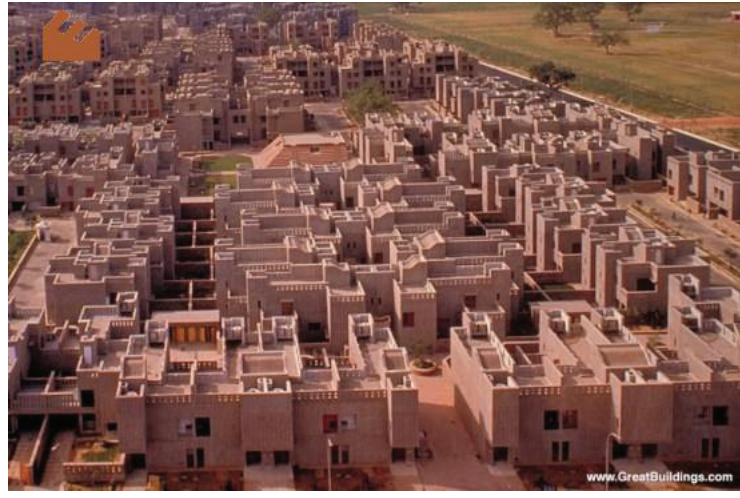

Figure 10. Asian Games Village, New Delhi

While practising he continued to teach in the School of Planning and Architecture where he remained updated with contemporary theories.

Raj designed buildings which were intended to be statements of architecture. His buildings were representative of Internationalism in the mohalla type settings of North India.

Thereby he brought about the merger of Indian sensibilities with an overall Western design style.

Being a theory-driven professor of architecture, with considerable expertise in History of Architecture, he found his calling in the symmetry, balance and materials used in the Moghul Architecture prevalent in North India.

Rewal's talent is to design huge projects which seem to have grown from the particular site.

\section{Discussion}

Though India has an architectural design tradition spanning a few thousand years, during the times of the colonization of India and particularly the British colonial period the architectural design activity was very meagre in the country. Some buildings of little importance were only designed by poorly trained draftsman and others during this period. At the time of Indian independence all design work was being done in Britain and In India there were a large number of civil engineers who were holding important postings for carrying out the construction works (Centre for Cultural Resources and Training (CCRT), n.d.).

When India gained independence the British handed over all the design work to the civil engineers who carried forward the work without any sensitivity and without understanding the benefits of good design.

Art schools trained draftsmen to assist British engineers who were employed to construct buildings for the civil and military administration. The technical Schools only provided rudimentary knowledge to produce functionally competent surveyors, store keepers and junior engineers. Even this minimal education was coveted because it offered the prospect of a white-collar job in government service and slowly the correlation between education and a secure government job got ingrained in 
public consciousness. There were no attempts at replicating the kind of architectural education that existed in England, at least not in the beginning. Later, in the early part of this century when architectural schools were established, the objectives remained vocational in nature and the pedagogy examination oriented. The curriculum attempted to mimic courses conducted in England without transmitting the spirit or milieu which existed in their class rooms. The approach was formulaic in nature and later, when more schools were established, they followed the same formula. However, this education did enable Indian graduates to register with the RIBA so it must have ensured a certain degree of competence and conformity with standards in England. But the educational objectives have not evolved since then and this stagnation is the source of complaint.

There was another parallel phenomenon going on at the same time which was to influence the course of modern architecture in India to come. Indian architects were going to Europe and America to seek higher education and cultural inspiration. The Indian architectural community took its inspiration from ideas developed in the western world. During the sixties these architects who received their education in the western countries commanded high positions as professionals as well as teachers. They taught, practiced and experimented with what they had learnt in the west against the harsh realities of India. The process of fermentation of ideas was turned on. There were many realizations that were to form the rational basis for architecture to come.

First of these realizations was that if we have to do anything worthwhile in India for Indians under Indian socio-economic and climatic conditions, the west was no place to look for inspirations or solutions. We will have to evolve our own patterns of development and physical growth, our own methods and materials of construction and our own expression of foregoing. This realisation created a sense of vacuum and because of the poignancy of the feeling of vacuum, the search began, and architects started looking in different directions for various answers. In each direction partial perception of truth was declared as the total truth. The fact however, remains that in each direction we have moved closer to rational basis of modern architecture. One of the first places where Indian architects looked for inspiration for expression of total architecture of India was our own village and folk architecture. Architects studied with keen interest the way people solved problems long before western influence was felt in India. From desert settlements of Jaisalmer, to village developments of hills, plains and sea-coasts, all became the focus of study. Complex planning were analysed and looked into for inspirations. There are some daring architects who have gone as far as to study the human settlements in the heavily populated areas of existing metropolitan cities, built without the help of architects, looking for solutions of high density, low rise economical housing; a challenging problem for India. It is the contention of these farsighted architects, with a hardnosed realism, that in such kinds of dense developments, with simple methods of construction and conventional low cost materials, when laid out in a planned manner, that we will find the answer urban housing for our really poor masses. While some of these architects were busy looking for answers in what we already have in our traditional settlements, others were exploring how industry can be made use of in solving the aspect of building problems. Prefabrication has potential in large scale housing, large span structures and industrial buildings on anywhere were repetitive units can be employed. But so far in India, industrialization of the building industry has not made great headway for lack of technological infrastructures to support it, therefore its influence is only limited to fascination of imagery. However, one aspect of technology that can be successfully applied in architecture is invention and manufacture of new building materials from industrial waste to replace the traditional building materials like steel and cement of which there are tremendous shortages.

It is here that Critical Regionalism came into play.

Critical Regionalism had always been around since the days of the earliest colonists. The foreigners brought with them ideas, technologies and socio-economic factors that they had experienced in their home countries and merged these with the local knowledge and techniques. This led to the indigenisation of imported architecture. However this was never conscientiously implemented by those in charge of construction work. By referring to the writings of Kenneth Frampton and seeing their application in the works of South Asian architects and by separately putting down the related issues in a point-wise basis it acts like a guide for the future architects of the Subcontinent to use.

\section{Conclusions}

Today, architecture has finally found a foot hold in the in the context of a rising India. Architecture is now being recognized as the creation of human spaces and it is no more a matter of public works, but one of sensitive design keeping in mind the cultural fabric of India. In fact architecture has found its origins even in the different regions within the country. Architecture in Western India (Rajasthan and Gujarat) is completely different from that found in the Eastern states. This can be seen in the architecture produced by young practising architects and the designs that are being developed in the studios of colleges in these areas. The influence of the great masters has surely imbibed the importance of Critical Regionalism in the minds of the present generation. This is despite a strong undercurrent of contemporary Western styles desired by most clients due to the aftermath of globalisation. The very source of architectural thought is in the educational institutions where the learning of design takes place. India is now fortunate to have a number of architectural schools located in the remotest parts of India and each school has 
been providing its students an insight to the local cultures while keeping themselves trained to deal with the current international trends. Finally, critical regional issues have been incorporated into most of the architectural thought of the professionals and each region has now achieved its own local taste and flavour.

\section{Funding sources}

This research did not receive any specific grant from funding agencies in the public, commercial, or not-for-profit sectors.

\section{References}

Ashraf, K. (n.d.). Muzharul Islam, Kahn and Architecture in Bangladesh. Retrieved from https://archnet.org/system/publications/contents/4011/original/DPT0619.pdf?1384778204

Bawa, G. (n.d.). ArchNet. Retrieved from http://archnet.org/library/parties/one-party.jsp?party_id $=73$

Binfield Havell, E. (1912). The ideals of Indian art. New York: E. P. Dutton and Company. Retrieved from https://ia802705. us.archive.org/34/items/idealsofindianar00haverich/idealsofindianar00haverich.pdf

Centre for Cultural Resources and Training (CCRT). (n.d.). Retrieved from http://ccrtindia.gov.in/modernarchitecture.php
Doshi, B. V., \& Steele, J. (1998). The complete architecture of Balkrishna Doshi: rethinking modernism for the developing world. Thames and Hudson.

Encyclopaedia Britannica. (n.d.) Charles Correa - Indian architect. Retrieved from http://www.britannica.com/EBchecked/ topic/138593/Charles-Correa

Frampton, K. (1983). Prospects for a critical regionalism. Perspecta, 20, 147-62. Retrieved from http://www.jstor. org/stable/1567071 ?origin=crossref\%5Cnhttp://frcll.com/ risd/spring_2010/weblog/frampton-critical_regionalism. pdf\%5Cnhttp://www.jstor.org/stable/1567071? origin=crossref https://doi.org/10.2307/1567071

History | NCBS. (n.d.). Retrieved from https://www.ncbs.res.in/ history/

Inglis, M. C. (2009). Doshi's philosophy of place | review | building design. Retrieved from http://www.bdonline.co.uk/doshi'sphilosophy-of-place/3151075.article

Lang, J. (2002). A concise history of modern architecture in India. Permanent Black.

Muzharul Islam Archive. (n.d.). Retrieved from http://www.muzharulislam.com/

Nangia, A. (2006). Post colonial India and its architecture - II. Retrieved from http://www.boloji.com/index.cfm?md=Conte nt\&sd=Articles\&ArticleID $=1027$

Ricœur, P. (1965). History and truth. Northwestern University Press.

Tzonis, A., \& Lefaivre, L. (1980). The Narcissist phase in architecture. Harvard Architectural Review, 1(Spring), 52-61. 